\title{
A fragilidade da condução política da defesa no Brasil
}

The fragility in the Brazil’s defense policy

\author{
Érica WINAND ${ }^{\bullet}$ \\ Héctor Luis SAINT-PIERRE ${ }^{\bullet \bullet}$
}

\begin{abstract}
Resumo: O presente artigo trata de avaliar em perspectiva histórica, algumas falhas na condução da política de Defesa no Brasil, fulcrais para se compreender a continuidade de um quadro de indevida participação militar e de ausência de controle civil na elaboração e implementação da mencionada pasta, incompatíveis com um contexto de governabilidade democrática. A despeito de algumas iniciativas no sentido de regulamentar os limites de atuação das Forças Armadas para que as mesmas não extrapolem suas funções e missões essenciais, e para que a política de Defesa seja revestida de um verniz público e civil - a exemplo da criação do Ministério da Defesa e da publicação da Estratégia Nacional de Defesa -, prevalece uma situação de fragilidade institucional e de vazio de poder público propícios para que a vontade militar permaneça conferindo o tom da Defesa nacional.
\end{abstract}

Palavras-chave: Brasil; Defesa; Controle Civil; Democracia.

Abstract: This article evaluates, under historical perspective, some lacks in Brazil's defense policy, that are central to understand the continuity of a framework characterized by the military participation and the civil absence in the elaboration and implementation process of Defense policy, incompatible with a democratic governance context. Despite some initiatives towards to regulate the armed forces limits, according their essential functions and missions, like the creation of the Defense Ministry and the publication of the National Defense Strategy, it prevails a situation of institutional fragility and public power vacuum that are conducive for the military actuation.

Keywords: Brazil; Defense; Civil Control; Democracy.

Duas são as particularidades que caracterizam a fragilidade da condução política da Defesa no Brasil. Uma delas consiste na edificação tardia de um Ministério civil para administração da pasta, a outra na manutenção de prerrogativas constitucionais para os militares e a persistência de ilhas de autonomia militar no cenário político nacional. Parece-nos que a morosidade, a estrutura militarizada, a ausência de civis entre seus quadros funcionais, os episódios de insubordinação e quebra da hierarquia, a opacidade nos assuntos estratégicos e da Defesa são consequência das prerrogativas e autonomia dos militares e, simultaneamente, as alimenta.

As discussões para a criação de um órgão que integrasse as três forças (Exército, Marinha e Aeronáutica) datam da Constituição de 1946 que evocou a necessidade de implantar um Ministério

\footnotetext{
- Professora Doutora - Departamento de História - Centro de Educação e Ciências Humanas - UFS - Univ. Federal de Sergipe - Av. Marechal Rondon, s/n, CEP: 49100-000, São Cristovão, SE, Brasil. Pesquisadora do Núcleo de Relações Internacionais da UFS e do GEDES - Grupo de Estudos de Defesa e Segurança Internacional da UNESP, campus de Franca. E-mail: ericawinand@yahoo.com.br

• Professor Livre Docente - Departamento de Educação, Ciências Sociais e Política Internacional e do Programa de Pós-graduação em História - Faculdade de Ciências Humanas e Sociais - UNESP - Campus de Franca - Av. Eufrásia Monteiro Petráglia, 900, CEP: 14409-160, Franca, SP, Brasil. Coordenador do GEDES - Grupo de Estudos de Defesa e Segurança Internacional e diretor do CELA - Centro de Estudos Latino Americanos da UNESP, campus de Franca. Coordenador da área "Paz, Defesa e Segurança Internacional" do programa interinstitucional UNESP/UNICAMP/PUCSP de pós-graduação em Relações Internacionais "San Tiago Dantas”. E-mail: hector.sp@uol.com.br
} 
único, mas que resultou na instituição do Estado-Maior das Forças Armadas (EMFA), na época, Estado-Maior Geral. ${ }^{1}$ Posteriormente, o presidente Castelo Branco defendeu a criação de um Ministério das Forças Armadas, assinando o Decreto-Lei 200 (25/02/1967) que previa estudos para elaborar um projeto de lei que promovesse a criação de tal ministério ${ }^{2}$. Alguns estudiosos ${ }^{3}$ acreditam que a intenção de Castelo Branco foi sincera, mas, a rivalidade existente entre as três forças falou mais alto e o projeto foi abandonado. A idéia foi retomada durante a Assembléia Nacional Constituinte de 1988 e obstaculizada pelo lobby das FA, voltando a ser cogitada em 1995 no plano de governo de Fernando H. Cardoso.

Em maio de 1996 foi criada a Câmara de Relações Exteriores e de Defesa Nacional (CREDN) no Conselho de Governo. A CREDN reunia os Ministérios das Relações Exteriores, de Justiça, da Marinha, da Aeronáutica, o Emfa, a Casa Civil, a Casa Militar e a Secretaria de Assuntos Estratégicos (SAE). Em setembro do mesmo ano, a recém criada câmara divulgou um Documento de Política de Defesa Nacional (DPDN) que buscou instituir um consenso sobre o planejamento da Defesa, bem como centralizar a administração da Defesa do Brasil sob o controle civil. A reformulação da Defesa brasileira pautou-se na ideia de "otimizar o sistema de defesa nacional, formalizar uma política de defesa sustentável e integrar as três Forças, racionalizando as suas atividades". Também compuseram os objetivos desta reformulação o alcance da transparência e da democracia no debate referente a este tema, uma maior articulação entre civis e militares e, também, entre as FA e o Itamaraty.

Até que o MD fosse criado, coexistiram no comando da Defesa o ministro extraordinário da Defesa - o senador Élcio Álvares, nomeado seis meses antes da institucionalização do órgão pelo qual seria responsável -, os Ministérios do Exército, da Marinha e da Aeronáutica, da Casa Militar e o Estado-Maior das Forças Armadas (EMFA). Após sua efetivação, o EMFA foi extinto, os três Ministérios foram transformados em Comandos e a Casa Militar transformada em subchefia do Gabinete de Segurança Institucional.

\section{Resultados efetivos da implantação do MD}

A criação do MD se traduziu em alguns avanços: 1-) ao nível discursivo, transluziu como o marco "formal" da existência de uma política civil de Defesa - uma vez que antes disto, o que havia era o completo descaso civil com este setor que aos olhos de muitos, deveria ser de competência exclusiva dos militares ${ }^{5}$; 2-) melhorou a imagem do país na comunidade internacional - uma vez que o fato de a Defesa ser conduzida por militares não era bem visto nem pelas entidades controladoras dos regimes internacionais de não-proliferação, nem pelo Conselho de Segurança, no qual, o Brasil lançara a candidatura a um assento; além de não ser compatível com os padrões de democracia referentes à nova ordem global; 3-) permitiu um nivelamento no diálogo internacional 
sobre Defesa, uma vez que as novas visões cooperativas e comunitárias lançadas na ordem da “interdependência" requerem a uniformização dos canais de interlocução, como uma garantia de que o tema seja tratado com base em valores e interesses comuns.

A despeito destes relativos avanços, o Brasil ainda convive com algumas incertezas na área da Defesa. A primeira é em relação ao fato de o Ministério da Defesa haver atingido uma consolidação institucional de forma totalmente autônoma em relação às Forças Armadas. A segunda, é se esta construção institucional favoreceu a consolidação ou, pelo menos, um aumento do exercício do controle civil sobre os militares ou uma maior transparência dos assuntos da defesa que fomente a formação de uma cultura democrática da Defesa. A terceira, que não deixa de se relacionar à primeira, diz respeito à garantia de que o Ministério da Defesa cumpra as metas colocadas pelo governo Fernando Henrique Cardoso, quando propôs a reformulação das bases da Defesa da Nacional. Fato é que o primeiro documento de política de Defesa do Brasil (o DPDN de 1996) ficou muito aquém das expectativas dos especialistas e estudiosos do tema, que esperavam algumas definições e limitações mais claras - particularmente em relação aos conceitos de "Defesa" e "Segurança" e ao emprego das Forças Armadas - nem cumpriu os objetivos norteadores da revisão da Defesa do Brasil, gerando discussões que perduraram até o governo Lula. Por isto, em 30 de Junho de 2005, pelo Decreto $\mathrm{n}^{\mathrm{o}} 5.484$, foi aprovado o novo Documento da Política de Defesa Nacional, que expressou ser o "condicionante de mais alto nível do planejamento de defesa, tendo por finalidade estabelecer objetivos e diretrizes para o preparo e o emprego da capacitação nacional, com envolvimento dos setores militar e civil, em todas as esferas do Poder Nacional", e que recebeu massiva contribuição dos militares para sua formulação.

Não obstante tenha-se expressado enfaticamente que esta reformulação anuncia uma nova era das relações civil-militares, caracterizada pela sintonia, pelo respeito ao jogo democrático e pelo intercâmbio de visões, ainda notamos que esforço não conseguiu remover a sociedade do seu desinteresse com estes temas; que o chamado "debate nacional" apenas limitou-se a convidar alguns expertos, escolhidos pelos próprios militares ou com a sua anuência, para proferir conferências intramuros; que ainda prevalece a supremacia dos valores militares na formulação da Defesa do Brasil. Talvez por estes fatores, quando se analisa o quadro funcional que ocupa o ministério o que se constata è uma ativa participação política dos militares, conforme denuncia a própria estrutura do Ministério da Defesa: apenas o cargo de Ministro da Defesa e o chefe do seu gabinete, entre os cargos principais da estrutura do ministério são civis. ${ }^{6}$ Até mesmo a nomeação do ministro, por parte do Presidente da República, depende (conquanto que informalmente) da aceitação prévia dos militares. Há, em algumas secretarias, cargos ocupados por civis, o que não caracteriza o Ministério como civil, isto é, o exercício de um civil no posto de ministro não garante o mando das Forças Armadas nem o efetivo controle civil da estrutura da Defesa Nacional. A autonomia das Forças 
Armadas se estende a sua relevante participação em todos os órgãos e gabinetes da estrutura da Defesa Nacional, tanto em funções de assessoria do Presidente e em sua participação no Conselho da República e o Conselho de Defesa Nacional, quanto nas funções de assessoria parlamentar e das comissões de Defesa Nacional do Congresso.

Acreditamos que o projeto de reestruturação das bases da Defesa do Brasil, começada sob o mandato de Fernando Henrique Cardoso, tenha sido elaborado dentro daquilo que o Estado Maior das Forças Armadas (EMFA) entendeu como adequado à garantia de manutenção da autonomia das Forças Armadas no cenário político nacional e no cerne das decisões nacionais relevantes. Criou-se, na verdade, mais um Ministério Militar, porque os comandantes das forças não perderam o status de ministros e mantiveram praticamente inalteradas suas funções de poder (continuaram a ser membros natos do Conselho de Defesa Nacional, por exemplo). Assim, os Comandantes de cada Força foram equiparados ao ministro da Defesa, pois se elegeu para estes, como foro de processo e julgamento, o Senado, o que somente é concedido ao Presidente da República e aos ministros de Estado. ${ }^{7}$

Outra manifestação da preeminência militar sobre os civis na correlação de forças nas deliberações das questões estratégicas e militares dentro do Ministério da Defesa ficou manifestamente clara na recente "renúncia" do Ministro José Viegas, "determinada" pelo presidente Lula como forma de resolver um conflito estabelecido entre o ministro e o Comandante do Exército. ${ }^{8}$ Portanto, ainda que formalmente as Forças Armadas mantenham a subordinação ao Presidente, não se provoca o exercício de teste da mesma, isto é, o exercício efetivo de mando civil. $\mathrm{Na}$ verdade, tanto o controle civil sobre todos os aspectos da Defesa, incluindo o orçamentário, assim como o exercício de mando é, na prática, inexistente, o que invalida a afirmação da existência de uma obediência material das Forças Armadas à autoridade civil constitucionalmente constituída.

Em outro campo, muito caro ao controle dos militares, como é o da formação e educação militar, fica clara a manutenção total da autonomia dos militares com relação a todas as instâncias da estrutura educativa e de ciência e tecnologia nacionais, legitimando mais uma de suas prerrogativas. Os estados-maiores e as respectivas diretorias e departamentos de ensino das forças planejam e fiscalizam o cumprimento dos seus objetivos educacionais sem qualquer consulta ao Ministério da Educação e sem admitir o controle e supervisão ao que se submete o resto da estrutura educativa nacional, desde o ensino fundamental até a pós-graduação. O poder civil não participa nem direta nem indiretamente, nem da formulação nem do controle, dos aspectos fundamentais da educação militar e lhe é vedada qualquer informação que solicite ao respeito, constituindo este, um dos aspectos que mais dificulta o seu estudo e analise por parte da academia. O Executivo Nacional, através do Ministério de Educação e Cultura (MEC), reconhece os cursos de formação de praças e oficiais como de nível elementar, médio ou superior, atribuindo sua equivalência com o sistema de ensino, mas não os avalia efetivamente. Tampouco reconhece a validade dos cursos de mestrado e 
doutorado criados pelos militares, com exceção do Instituto Militar de Engenharia (IME) e do Instituto Tecnológico da Aeronáutica (ITA), por suas condições de ingresso, estrutura curricular e capacitação docente e por permitirem a supervisão e controle por parte do ministério. O MD não tem ingerência direta nos cursos das FA, a não ser quando os militares se matriculam nos cursos de altos estudos da Escola Superior de Guerra (ESG), que é de responsabilidade do ministério. O Legislativo somente acompanha o andamento da organização, preparo e emprego das FA, além de votar o seu orçamento, mas sem interferir na educação militar profissional. Uma das razões da omissão política mais este assunto relativo à Defesa Nacional é a falta de interesse e capacidade de muitos parlamentares para tratar adequadamente das questões de defesa nacional. ${ }^{9}$ Portanto, o sistema educativo das Forças Armadas (assim como à Justiça Militar) constitui um dos segredos melhor guardados pela instituição, até por ser neste nicho que se estabelecem os princípios, os valores e as doutrinas que formam a visão do mundo militar e que serão seguidos pelos jovens postulantes a oficiais. $\mathrm{O}$ fato é que propor um estudo acadêmico externo sobre esse sistema, ainda que seja meramente histórico, produz um inocultável mal-estar nas casernas. As idas e vindas na procura de autorização para levar as pesquisas nesta área, na maioria das vezes, é insuficiente para abrir o zelado cofre. A cultura do segredo, cara para os fardados, é mais um entrave que oculta o que deveria ser público. Esta atitude impede que se realizem sérias pesquisas que poderiam redundar na melhoria da formação militar.

Nesta medida, vale se perguntar se a dificuldade em submeter democraticamente os militares ao poder civil pode ser atribuída apenas à resistência dos próprios militares ou a uma conivência histórica da elite política civil brasileira. Insistimos: a criação do Ministério da Defesa teria feito parte de uma tentativa, ainda que em vão, de submeter os militares ao controle democrático por parte dos civis, ou teria sido, mais uma vez, um pacto entre líderes militares e civis para garantir a manutenção das prerrogativas e as ilhas de autonomia? Ou ainda, poderia ter sido a criação do Ministério da Defesa uma concessão militar antes que ter que ceder a uma imposição civil ou mesmo que tenha sido concedido como um instrumento de barganha para negociar outros objetivos, talvez como meio de melhorar a reputação do Brasil através de uma vestimenta moderna e democrática? ${ }^{10}$

\section{Histórico da relação entre as FA e a sociedade no Brasil pós-regime militar}

Uma análise da distensão do regime autoritário de base militar no Brasil e que deu lugar à transição, passando pela elaboração da Constituição de 1988 até desembocar no processo da transformação dos Ministérios Militares em Comandos e a criação do Ministério da Defesa, mostra que as Forças Armadas vem, historicamente, resistindo a mudanças ou condicionando as mesmas à 
garantia de suas prerrogativas e espaços de autonomia para interferir no tabuleiro do jogo político nacional.

O General Ernesto Geisel foi o artífice do projeto de Distensão militar. Ele deixou claro em seus discursos, com uma sinceridade próxima do cinismo, que a abertura do regime não objetivava precipuamente o retorno à democracia, mas apenas consistia num afrouxamento das tensões existentes, visando ao estabelecimento de um consenso que viabilizasse a consecução dos objetivos da denominada "Revolução de 64" - como os militares se referem ao Golpe Militar que fechou o regime democrático nesse ano. Com isto, como mostra-nos Mathias (1995, p.79), a continuidade dos princípios do regime militar é "parte constitutiva da mudança que, por sua vez, está relacionada à não-ruptura das bases sob as quais se erigiu o processo revolucionário”. A restauração do governo civil seria permitida desde que fosse mantida intacta a capacidade de intervenção militar na política (MATHIAS, 1995, p.88). O governo militar só concordava com a instalação da democracia, caso ela afastasse qualquer possibilidade de contestação da ordem sócio-econômica proposta pelo processo revolucionário. Ernesto Geisel, que foi o presidente militar que gozou de maior prestígio, ${ }^{11}$ por razões idiossincráticas, soube conduzir com cautela o processo de distensão "lenta, segura e gradual", de modo a garantir a eliminação dos entraves para a vigência da Constituição que os militares tinham ditado em 1967, asseverando a consecução do chamado "desenvolvimento político" (que para eles significava a somatória do desenvolvimento econômico com o social) e afiançando um sucessor (que resultaria sendo o Presidente Figueiredo) que também estivesse apto a devolver o governo aos civis, desde que a "abertura democrática" se desse com "responsabilidade".

O governo de José Sarney - que sucederia pelo voto indireto e pela morte inesperada do titular ao cargo -, já caracterizado por um processo de "transição à democracia" também foi fruto de árduas negociações entre civis da aliança democrática e os líderes militares. Como aponta Eliezer Rizzo de Oliveira (1994, p.106), o deslocamento das Forças Armadas do centro do poder político cedeu lugar a um quadro "de tutela sobre o governo civil". O aparelho militar teve, durante o governo de José Sarney, seu espaço mantido, sendo-lhe ainda reservada a prerrogativa de influir nas decisões governamentais dos civis (OLIVEIRA, 1994, p.111). A presença do Ministro do Exército, General Leônidas Pires Gonçalves, ao lado do presidente José Sarney, “emitindo opiniões não só de sua pasta, mas de todos os assuntos que considerava de importância [...]", elucida a condução do jogo político pelos militares (MYAMOTO, 2000, p.450).

Além disso, a tarefa atribuída a Sarney, de chamar a uma Assembleia Constituinte que elaborasse uma Constituição compatível com as exigências democráticas, foi compartilhada e tutelada pelos militares ${ }^{12}$. Como resultado disto, a Constituição de 1988 acabou mantendo legal o pleno exercício da função interventora das principais lideranças militares, por meio de artigos imprecisos e ambíguos, como o de número 142 que define quem e em que condições pode solicitar 
e quem se responsabilizar pelo emprego das FA. As questões relativas à Defesa e à Segurança e aos temas a elas vinculados são tratadas de modo bastante dispersos na Carta Constitucional. A estrutura de poder concede à União a primazia no tratamento e encaminhamento das questões da Defesa. Cabe-lhe a responsabilidade por assegurar a Defesa Nacional (art. 21, III), como também a disposição de autorizar que forças estrangeiras transitem pelo território nacional ou nela permaneçam temporariamente (art. 21, IV); a adotar as medidas nacionais previstas na constituição para tratar de ameaças ou situações internas que comprometam ou envolvam questões de Segurança e Defesa Nacional, a saber, o Estado de Sítio, o Estado de Defesa e a Intervenção Federal (art. 21, V); assim como a físcalização e autorização para produção e comércio de material bélico (art. 21, VI), além de um estrito controle sobre a atividade nuclear, na exploração de serviços e instalações, exercendo o monopólio sobre a pesquisa, a lavra, o enriquecimento e reprocessamento, a industrialização e o comércio de minérios nucleares e seus derivados (art. 21, XXIII), sendo que as atividades nucleares realizadas em território nacional somente poderão ser permitidas se voltadas para fins pacíficos e mediante aprovação do Congresso Nacional. ${ }^{13} \mathrm{O}$ emprego das Forças Armadas como instrumento de garantia da lei e da ordem é da responsabilidade do Presidente, por iniciativa própria ou em atendimento a pedido de qualquer dos poderes constitucionais, através do Presidente do Supremo Tribunal Federal, do Presidente do Senado Federal ou do Presidente da Câmara dos Deputados, no âmbito de suas respectivas áreas. A atuação das Forças Armadas ocorrerá de acordo com as diretrizes do Presidente e após esgotados os instrumentos destinados à preservação da ordem pública, da incolumidade das pessoas e do patrimônio, relacionados no art. 144 da Constituição Federal que cuida da Segurança Pública. Nestas passagens se encontra a principal brecha deixada pela Constituição para interpretações jurídicas que permitam o desvio de missão das FA. Por meio dela, fica dependente um determinado tipo de destinação militar à iniciativa de qualquer dos Poderes da República, ou seja, na prática, além do presidente, outras autoridades podem decidir sobre o recurso às Forças Armadas. Além disto, as possibilidades para convocação das Forças Armadas são amplas, podendo descaracterizar sua missão essencial. Deparado com a inocultável incapacidade de solucionar os graves problemas de segurança pública que se abatem sobre a sociedade, o governo brasileiro, que não se atenta aos limites constitucionais, tem batido com maior frequência às portas dos quartéis, buscando soluções para a repressão do tráfico de drogas e do crime organizado que os instrumentos constitucionalmente consagrados não oferecem. ${ }^{14}$

Uma particularidade do Brasil e que dificulta a reflexão sobre missão e emprego das FA, além da falta de cultura da Defesa na sociedade e da ausência de especialistas civis no tema, é o fato de que este país carece de forças de contenção intermediária. Diferentemente de outros países de América do Sul, o Brasil não conta com gendarmerías, ou carabineros, prefecturas costeiras e outras formas armadas que podem ser empregadas em caso de insuficiência das forças policiais ou 
em caso de estas serem superadas ou mesmo em operações especiais como, por exemplo, o combate ao narcotráfico e ao crime organizado. Ante esta deficiência, em casos emergenciais em que as forças do crime ou a desordem superem as forças repressivas, o Estado se sente necessitado de empregar suas forças de combate, isto é, as suas FA. Este fato, somado à história recente de governos autoritários de base militar, mantém viva a sensibilidade para os desvios de missões e alerta para os detalhes constitucionais, assim como exige um permanente cuidado político para manter separados os conceitos de "Defesa" e "Segurança Pública", esta última objeto das diversos corpos de Polícias, reservando aquela às FA. Ainda assim, zonas cinzentas e nebulosas permanecem inalteradas no texto constitucional, o que torna política a decisão de quando, em que condições, com que objetivo e com que intensidade empregar as FA no âmbito interno.

Em abril de 1991 foi aprovada pela Câmara de Deputados, a partir de Emenda e de diversas negociações, a Lei Complementar sobre Forças Armadas que corrige as distorções constitucionais que aninhavam no Cap. 142 acima mencionadas. Mas, em suma, o presidente José Sarney finaliza seu governo tendo atendidas praticamente a totalidade das demandas militares: o não julgamento dos excessos da repressão durante o regime e a preservação da autonomia militar com baixo grau de autoridade presidencial sobre o aparelho militar; confirmação do quadro de tutela, assegurado também pelo controle militar sobre os programas nucleares, como o Programa Nuclear Paralelo (PNP) e manutenção das três forças singulares como Ministérios (OLIVEIRA, 1994, p.189).

Durante o governo Collor podem se notar algumas modificações no quadro das relações entre civis e militares. Uma delas foi a promulgação da Lei Complementar citada acima. Mas houve outras talvez mais significativas: Collor encolheu relevantes funções militares ao promover mudanças no Gabinete Militar, no EMFA e na área do Serviço de Informações. Ao extinguir o Serviço Nacional de Informações (SNI), criar a Secretaria de Assuntos Estratégicos (SAE), e desprover de status ministerial o EMFA e o Gabinete Militar, o presidente contribuiu para a desmilitarização do nível superior de deliberação do poder do Estado e da administração do Planalto. Além disto, Collor buscou desarticular o Programa Nuclear Paralelo (PNP), desestruturando a militarização do setor científico e tecnológico. Porém, o governo Collor significou uma nova fase de sobrevivência da dialética "ruptura e continuidade", pois, ao mesmo tempo em que promoveu mudanças consideráveis, não conseguiu extinguir os Ministérios das forças singulares. Estas últimas convenceram o presidente de que a criação do Ministério da Defesa só era compatível com o sistema parlamentar de governo, entre outros argumentos. Collor, porém, foi prudente na escolha dos ministros militares. Com algum tino procurou localizar entre os altos mandos militares lideranças aptas a estabelecer uma negociação conciliatória com o governo: a pressões do Almirante Mário César Flores (ministro da Marinha), do General Carlos Tinoco (ministro de Exército) e do Brigadeiro Sócrates Monteiro (ministro da Aeronáutica) abandonaram o 
aspecto institucional e incorporaram um caráter de associação. Os perfis destes ministros não se relacionavam ao regime militar, nem ao quadro tutelar do governo anterior.

Apesar de os Ministérios apresentarem um bom comportamento, Collor deixa lacunas abertas no tocante à "crise de identidade militar" condizente à adaptação das funções militares às demandas do pós Guerra Fria, gerando novos conflitos que poderiam, de uma outra forma, comprometer a democracia. Os novos papéis atribuídos às Forças Armadas causam uma mudança nas condições institucionais, materiais e políticas das mesmas, criando um sentimento de rejeição no interior da caserna. Ademais, as duas hipóteses de guerra que condicionavam o preparo e o emprego militar com a Argentina, como inimigo externo tradicional, e contra o subversivo como inimigo interno foram descartadas no desenvolver da nova ordem mundial (ordem globalista, regionalista e cooperativa, explicada pela crescente interdependência recíproca). Collor saiu do governo sem que fossem claramente definidas as novas atribuições das Forças Armadas, o que permitiu um agravamento gradual das tensões no seio das mesmas e uma pesada herança para o próximo governo.

A crise político-institucional do governo Collor, que terminou no episódio do impeachment do presidente, foi uma experiência comprovadora de que os ministérios militares não almejavam naquele momento nenhum tipo de intervenção, uma vez que a fragilidade da situação permitiria tal ocorrência e ela não aconteceu. Mas, por outro lado, poder-se-ia pensar que o impedimento do presidente Collor facilitaria seus projetos e deixariam ao sucessor, seu vice-presidente, Itamar Franco, numa situação de muita fragilidade político-institucional e, por tanto, sensível às demandas do setor fardado. Pode ser meramente especulativo, mas é fato que foi sobre o governo de Itamar Franco que os reflexos da crise interna às Forças Armadas incidiram mais notavelmente. A autoridade presidencial sobre as Forças Armadas, recuperada por Collor, foi visivelmente enfraquecida no governo de Franco, o que permitiu a abertura de uma forte luta política em torno da definição dos ministros militares. Por fim, como resultado desta luta, os ministros Flores, Tinoco e Monteiro foram substituídos pelo Almirante Ivan Serpa, pelo General Zenildo Lucena e pelo Brigadeiro Lélio Viana Lobo, refletindo o jogo de trocas entre o esquema político e o militar, tal como ocorreu com Sarney e seu ministro do Exército, Leônidas Pires Gonçalves. Por este quadro de fragilidade política, o governo de Franco representou o retorno a um quadro de tutela, como definira Eliezer Oliveira (1994, p.314).

Enfim, com este breve histórico, pretendemos mostrar que a autonomia ou a subordinação dos militares em relação ao poder civil é um processo de idas e vindas e que neste se inclui a longa relutância em torno da criação do Ministério da Defesa. A criação do mesmo foi ferrenhamente combatida pela Marinha, pelo Exército e pela Aeronáutica na Constituinte e isto esteve relacionado ao fato de as forças políticas pró-criação atribuir ao Ministério um caráter de instrumento de 
controle civil e de restrição da autonomia política dos militares e de equilíbrio entre as forças. No governo Collor, a criação do Ministério da Defesa sofreu resistência não pela questão da diminuição da autonomia das Forças Armadas, nem pela questão de equilíbrio entre as forças (pois isto parecia não ser problema, dado o razoável comportamento nos ministros militares de Collor), mas naquele momento relacionou-se mais à crise de identidade vivida pela instituição. Afinal, embora o fim da Guerra Fria tenha anunciado "novos tempos" e novas prioridades, não seria plausível que os militares, revisassem do dia para a noite, seus valores, seus conceitos políticos e estratégicos, suas hipóteses de conflito e doutrinas historicamente construídos. Ou seja, enquanto que se obscurecia o entendimento sobre missão, papel e função das Forças Armadas na nova era, não houve atualização da doutrina militar e nem modificação substancial do seu comportamento. Por isto, nem sempre mostravam acordo em relação às novas missões que lhe eram atribuídas. Por outro lado, o fato de o Exército ter se preparado durante mais de vinte anos para combater o inimigo interno, fazia com que sua estrutura fosse essencialmente voltada ao plano nacional, o que temiam que fosse desmantelado no caso de que se criasse um Ministério da Defesa que propusesse novas projeções estratégicas para o país. Nesse posicionamento conservador das FA é possível se destacar a exceção constituída pelo pensamento do Almirante Mário César Flores, ministro da Marinha. Dono de um pensamento liberal, ganho projeção nos médios de informação quando decidiu abrir ao público as instalações nucleares navais que até esse momento eram mantidas no maior segredo. Ele também foi um ferrenho defensor da criação do Ministério da Defesa, ainda que sustentando, não sem razão, que o controle civil das Forças Armadas dependesse muito mais da eficiência do Estado democrático e da mentalidade da sociedade do que da instituição do referido órgão.

Já durante o governo de Itamar Franco, como sugere Oliveira (1994, p.317), teriam sido criadas as condições para que a eventual "adoção do Ministério da Defesa seja destituída do caráter fundador de um novo equilíbrio entre as armas", constituindo um novo ponto de instabilidade. De forma geral, acredita-se que o Ministério da Defesa seria uma consequência natural, partindo das necessidades militares e de uma política de defesa que as satisfizesse. Assim, as forças defenderam que não se poderia criar um Ministério da Defesa antes de uma deliberação parcimoniosa sobre algumas das definições centrais para toda sua organização e estrutura, bem com formulada e aprovada uma consistente e eficiente Política Nacional de Defesa.

Esta resistência militar às mudanças, somada à falta de uma clara proposição dos civis sobre o tema e da confusão do conceito de Defesa com questões estritamente militares colaborou para que enquanto em diversas partes do mundo, estruturas semelhantes ao Ministério da Defesa fossem edificadas já pós-II Guerra, no Brasil, só se contaria com uma condução unificada sob o comando civil, ao menos do ponto de vista formal, apenas no fim do Século XX, ainda assim, encontrando, até os últimos dias, diversas e resistentes barreiras para sua consolidação. Além disto, como o 
histórico que acabamos de apresentar pareceria prognosticar, o resultado mais plausível para esse processo de construção institucional do Ministério da Defesa não poderia ser outro que uma estrutura frágil e militarmente controlada, incapaz de cumprir eficazmente com suas funções em sua plenitude, seu próprio processo de criação a condenava. Em primeiro lugar, porque assim que o presidente Fernando Henrique Cardoso cogitou a ideia, em lugar de induzir estudos acadêmicos e um debate político nacional sobre o tema, se precipitou a solicitar assessoria ao ministro do EMFA, General Benedito Onofre Leonel, para concepção do Ministério. Em segundo lugar, porque, pela ignorância e desinteresse geral da sociedade civil sobre as questões concernentes a área da Defesa e Segurança, todas as discussões formais sobre a instituição do órgão contaram com a supervalorização da opinião militar, cuja presença era massiva. O próprio deputado Benito Gama, relator do projeto de emenda constitucional (PEC) declarou que o Ministério da Defesa seria uma espécie de rainha da Inglaterra: reina, mas não governa (ZAVERUCHA, 2005, p.215). Além disso, Fernando Henrique Cardoso não conseguiu nomear Ronaldo Sardemberg para ministro e, cedendo à contestação dos militares, partiu em busca de outras alternativas que tranquilizassem os ânimos dentro da caserna.

Enfim, o único aspecto que parece, dentro do Ministério da Defesa, ter decisão totalmente civil, é a questão orçamentária, que por sua vez, não é conduzida sem equívocos.

À guisa de conclusão sob a administração de FHC: Apesar de alcançar significativos avanços, quais sejam: a instituição "formal” da política de Defesa, por meio do estabelecimento da DPDN e, em seguida, do MD e a nivelação do diálogo internacional sobre Defesa, o resultado final das reformas não esteve perto de dar ao Brasil a condição de país plenamente democrático, com um controle civil sobre os militares garantido. Cardoso, além de deixar lacunas para a atuação militar no MD, aprofundou as feridas das FA ao designar-lhes novamente uma missão (Amazônia) e não atribuir-lhes, no entanto, meios materiais que lhes permitissem cumprir esta missão. Assim, se o governo obtivera algum sucesso na estabilização das relações civil-militares, por meio da atenuação da crise de identidade nascida no governo de Collor, logo a mágoa do militar veio à tona quando, sem definir claramente os objetivos da Defesa do país e, continuando sem delimitar as fronteiras entre Defesa e Segurança, a atuação dos militares como forças policias cresceu, assim como continuou sem modernização todo o aparato da Defesa e continuaram desatualizados os salários dos militares. Também não se pensou uma nova base cultural para estruturação de uma Defesa compatível com os novos tempos. Se dentro das academias militares o sistema educacional não se preocupou com o novo "profissionalismo" a ser implantado, fora dela tampouco foram incentivados debates que levasse à população um maior conhecimento sobre o tema. Os reflexos dessas falhas são assistidos atualmente, como mostrará a próxima parte deste texto. 


\section{A Defesa no governo Lula: Implicações atuais}

Durante a campanha eleitoral que colocaria Lula no poder, o candidato apresentou aos militares as seguintes propostas para o setor da Defesa: ${ }^{15}$ Orçamento para as três forças, exigindo a participação do Congresso em debates de projetos de Defesa de quatro em quatro anos; investimentos destinados à recuperação do setor de inteligência; reforço das áreas de fronteiras, principalmente na região amazônica; revogação do Tratado Inter-Americano de Assistência Recíproca (TIAR) e a substituição deste por um de cooperação regional; fomento de movimento de cooperação militar liderada pelo Brasil; acabar gradualmente com a obrigatoriedade do serviço militar e substituí-lo pelo civil; dar continuidade à compra dos caças, dando prioridade ao consórcio que propiciar transferência de tecnologia do software e geração de empregos. Durante a apresentação do seu programa aos militares, ${ }^{16}$ abarcou temas como: equipamento das forças; plano de Defesa Nacional; aumento em quatro anos de $1 \%$ para $2 \%$ do Produto Interno Bruto do País (PIB) os recursos do Orçamento destinados à Pesquisa e Tecnologia de Defesa; aumento dos salários e retomada da paridade da aposentaria entre militares da ativa e inativos, caçada por meio de uma Medida Provisória editada pelo presidente FHC. Quanto ao serviço militar, Lula disse que poderia ser instrumentalizado como forma de inserção social dos jovens brasileiros que estão fora do mercado de trabalho.

José Viegas Filhos, primeiro Ministro da Defesa nomeado pelo Presidente Lula, esteve no Clube Militar do Rio de Janeiro, onde apresentou as principais preocupações do Ministério. ${ }^{17}$ De acordo com o seu discurso, ${ }^{18} \mathrm{o}$ reaparelhamento das FA seria postergado em função de outras prioridades, como o desenvolvimento social. Na ocasião, afirmou que a função essencial das FA seria defender a soberania e a integridade do território nacional, entendendo que para isso seria necessário preparar, adestrar e aparelhar os efetivos, deixando claro que a "dissuasão" permanecia sendo o elemento básico da estratégia brasileira da Defesa ${ }^{19}$. De acordo com o Ministro, a orientação das FA já estaria adequada aos novos tempos e os valores democráticos cultivados após essas transformações alteraram o velho conceito de "Segurança do Estado" para o de "Segurança Cidadã", "substituindo a preocupação excessiva com a segurança do aparelho do Estado por uma atenção vinculada propriamente à segurança da nação, que prestigia os cidadãos e a sua escolha dos destinos políticos do país", conforme suas palavras. Porém, parece que o Ministro não soubera definir com precisão os limites dessa nova "Segurança Cidadã", ampliando ainda mais o leque das ditas "tarefas subsidiárias". Além disso, ao invés de recorrer ao legislativo para receber auxílio na formulação dessas questões, o Ministro solicitou um debate fechado apenas com os militares sobre a extensão que deveria ter o envolvimento das FA em tarefas alheias ao papel constitucionalmente consagrado, colocando-lhes três alternativas: a absoluta abstenção das FA de intervir nessas tarefas; uma posição intermediária, segundo a qual, as FA, sob determinação legal, desempenhariam apoio 
às forças policiais no combate às novas ameaças e, por último, uma posição radical de envolvimento direto no combate a essas atividades. Ademais, o Ministro defendeu a participação das forças em programas sociais, com o denominado "Fome Zero" afirmando: "A valorização das FA e o comprometimento com uma sociedade mais justa são metas que se casam”.

Para Viegas, seriam prioridades, na nova era Pós-11/09, atualizar a base conceitual do pensamento estratégico nacional diante da realidade mundial e das necessidades de defesa do País. Para isso, seria conveniente revisar as grandes linhas de pensamento estratégico para definir uma estrutura militar adequada às demandas da Defesa. Assegurar a proteção da Amazônia foi outra prioridade colocada por Viegas, respondendo a uma velha reivindicação das FA que atribuem à Amazônia grande importância estratégica pelo tamanho da fronteira que o Brasil tem nessa região com vários países, absolutamente desguarnecida. A terceira prioridade diz respeito à consolidação do papel do Brasil como promotor da integração regional e hemisférica em matéria de defesa, bem como a sedimentação de sua presença nos foros internacionais de defesa, realçando a posição brasileira na manutenção da paz mundial. Este objetivo é coerente com o novo perfil da política externa brasileira, a chamada "diplomacia ativa" e refere-se à projeção estratégica do Brasil na região (particularmente na América do Sul), bem como no âmbito hemisférico, visando consolidar e aumentar sua participação internacional na manutenção da paz no mundo. Embora reconhecendo que a região vive uma etapa de consolidação das democracias e de paz garantida, impulsionada especialmente pelo Mercosul e pela Comunidade Andina, o Ministro alertava para a vulnerabilidade a ações clandestinas de caráter transnacional, o que exigiria maior empenho na "proteção das fronteiras, vigilância do espaço aéreo e patrulhamento marítimo e fluvial”. Em consonância com aquela "diplomacia ativa", declarava "o reconhecimento do Brasil como potência regional e, consequentemente, a intensificação da participação na intermediação de conflitos internacionais na manutenção de uma força preparada para integrar missões internacionais de manutenção da paz”. Prometia manter e aumentar a participação externa do Brasil através participação das suas FA em vários operativos e atividades em todas as partes do mundo. ${ }^{20}$ Os demais objetivos da Defesa, anunciados por Viegas seriam: "Promover a obtenção, a modernização e a adequação dos meios necessários ao emprego das FA", elaborando-se o documento de "Estratégia Militar Brasileira", no qual seriam definidas as bases para o planejamento do reaparelhamento e a interoperabilidade e interconectividade das forças; minimizar a dependência externa quanto aos recursos de natureza estratégica para a defesa do País, incentivando a pesquisa para o desenvolvimento de tecnologias atuais e o desenvolvimento da indústria bélica nacional; aperfeiçoar a capacidade das FA para operar de forma combinada ou conjunta; modernizar as estruturas organizacionais e os processos administrativos, com ênfase nos sistemas de controle, gestão da informação e na qualidade da ação gerencial; desenvolver e modernizar a capacidade de atuação da aviação civil, e, por fim, 
intensificar a divulgação das ações desenvolvidas pelas FA em prol da sociedade brasileira e valorizar o soldado.

$\mathrm{O}$ ex-ministro Viegas contribuiu fundamentalmente para as discussões que geraram o novo Documento de Política de Defesa Nacional, divulgado no ano de 2005, quando o Ministério já se encontrava sob chefia de José Alencar. Prova disso é que o documento apresenta ideias semelhantes ou idênticas àquelas prenunciadas pelo ex-Ministro antes de sua renúncia, como a noção de Defesa. Em pronunciamento ao Instituto Rio Branco ${ }^{21}$, Viegas defendeu a elaboração do Livro Branco da Defesa e adotou como conceito de Defesa Nacional: “o conjunto de medidas e ações do Estado, com ênfase na expressão militar, para proteção do território, da soberania e dos interesses nacionais contra ameaças preponderantemente externas potenciais ou manifestas.” A reprodução dessas ideias aparece no DPDN de 2005, quando se busca uma distinção entre Defesa e Segurança:

I.- Segurança é a condição que permite ao País a preservação da soberania e da integridade territorial, a realização de seus interesses nacionais, livre de pressões e ameaças de qualquer natureza e a garantia dos cidadãos ao exercício dos direitos e deveres constitucionais;

II.- Defesa Nacional é o conjunto de medidas e ações do Estado, com ênfase na expressão militar, para a Defesa do território, da soberania e dos interesses nacionais, contra ameaças preponderantemente externas, potenciais ou manifestas $^{22}$ (grifo nosso).

A noção de Segurança do novo DPDN também reproduz a proposta de Viegas de "Segurança Cidadã", assim como o documento enfatiza as iniciativas de cooperação entre as FA vizinhas para garantia da paz e da estabilidade regionais. Esta, aliás, é uma virtude do Ministro que não deve passar em branco: ao incentivar a cooperação regional, contribuiu de forma relevante nas discussões que geraram o novo documento da Defesa, além de se fazer notável por inaugurar diálogos entre civis e militares, manifestos em numerosos discursos e conferências; também por participar ativamente das reuniões de ministros da Defesa, as quais se deram muito mais frequentemente do que na gestão de seus sucessores, o que aponta que após sua renúncia, houve um novo retrocesso na trajetória civil rumo à solução das questões da Defesa no Brasil. Viegas contribuiu para que o DPDN intensificasse o processo de harmonização da Defesa com a Política Externa, ao fomentar o diálogo com outros países da América do Sul. Porém, a distinção entre Defesa e Segurança que prenunciou e que apareceu no novo DPDN, seja por incompetência ou por falta de vontade política, não alcançou uma clara distinção conceitual entre a Defesa e a Segurança, o que não é um mero problema de semântica, mas de ordem operativa, porque é em decorrência disto que se estabelecem as missões das FA. Sem ânimo para discutir as "ameaças potenciais", que, por sua amplitude semântica, configura qualquer situação em qualquer momento, enfatizamos acima o advérbio "preponderantemente" porque é ele quem abre decididamente as portas para o emprego das FA na 
contenção de ameaças originadas externa ou internamente, podendo ser elas de qualquer natureza. Este instrumento de intervenção sinaliza a ampliação das missões das FA.

\section{A Estratégia Nacional de Defesa (END)}

Embora a promulgação de um documento sobre a defesa brasileira não tenha sido uma novidade, porque o presidente Lula a havia anunciado várias vezes em seus discursos, sim, é possível especular sobre as razões que precipitaram a promulgação da END. O Brasil precisava de algum documento que pudesse apresentar para suprir a ausência de um Livro Branco, que apresentasse os princípios, fundamentos e objetivos da Defesa e da projeção estratégica do Brasil. Por um lado, pelo visível contraste com seus vizinhos sul-americanos - em direção aos quais se orienta a política externa brasileira do governo Lula - quase todos eles contando com seus Livros Brancos, alguns dos quais com amplo debate nacional que, ao declarar publicamente suas sensibilidades e projeções estratégicas, destacaram o déficit brasileiro nesse aspecto. Por outro lado, as viagens empreendidas por Jobim, buscando mercados onde reequipar o parque bélico das FA brasileiras, mostraram a necessidade de abrir a "caixa preta" da Defesa e explicitar suas intenções em sua área de projeção. Com efeito, alguns governos europeus, ainda que ávidos por vendas que alavancassem seus países em meio a crise econômica, condicionaram as negociações a uma perspectiva mais clara da política de defesa brasileira. Também incidiu na promulgação a busca por coerência na política regional: o Brasil propôs a criação do Conselho Sul-Americano de Defesa e, inclusive, sugeriu a elaboração de um "Livro Branco Regional de Defesa" que o próprio Brasil ainda não possui nacionalmente (um dos poucos países na região que arrasta essa dívida).

Finalmente, era notória a necessidade de completar ou avançar no fortalecimento da condução política nos assuntos da Defesa, ainda dependente do monopólio militar nesses temas. Este fortalecimento, lento e gradual, precisava institucionalizar a inserção dos nervos do governo na fibra muscular dos meios da Defesa para possibilitar a governabilidade. Um passo fundamental nessa direção foi a criação do $\mathrm{MD}$, não obstante, não garantiu a plena condução política das FA. Quiçá pela falta de funcionários civis capacitados para a função, o ministério acabou sendo "mobiliado" - para usar a metáfora do ex-ministro da Defesa, José Viegas - basicamente com funcionários militares que mantiveram as prerrogativas constitucionais e a autonomia das forças. $\mathrm{O}$ refluxo das FA dos espaços políticos do ministério poderia agora ser alcançado por um aspecto que nunca antes havia sido atendido: a reorganização das FA institucionalizando sua condução política mediante uma clara cadeia de comando. Este aspecto, segundo o ministro Nelson Jobim, foi atendido pela END que "fixou as bases para a consolidação do poder civil na direção da defesa nacional, com a determinação dos papéis que cabem nesse processo aos civis e ao braço militar Marinha, Exército e Aeronáutica". ${ }^{23}$ 
Em 7 de setembro de 2007, por ocasião do dia do Exército, o Governo Lula solicitou e o ministro da Defesa prometeu entregar ao país, um ano depois, uma reformulação da política de defesa ou um Livro Branco da mesma. Tanto nesse como em outros discursos se prometeu que seria gerado um amplo debate nacional que cristalizaria os acordos da comunidade nacional da defesa em um documento. Não se cumpriram os prazos nem houve debate sobre a END que foi apresentada tardiamente e surpreendendo à incipiente comunidade de defesa brasileira que esperava participar no anunciado debate que nunca existiu, apesar de Jobim ter declarado que "o tema começou a estar presente na mídia, no Congresso, nos quartéis, nas reuniões empresariais, nas Universidades" como metodologia democrática de deliberação. ${ }^{24}$ Se houve algum debate ou se o tema rondou o ambiente acadêmico, foi produto da iniciativa dos próprios acadêmicos na esperança de que em algum momento a comunidade fosse convocada para discutir o tema nacionalmente. ${ }^{25}$

O Presidente Lula colocou a frente da elaboração da END, ademais do MD, o recém nomeado Ministro de Assuntos Estratégicos, Mangabeira Hunger, mas longe de melhorar o projeto, na realidade a END parece ter tentado contemplar as expectativas, a vezes opostas, de diferentes atores, entre eles cada uma das três FA. Talvez querendo contentar a gregos e troianos parece não ter satisfeito a nenhum, porque as críticas, especialmente dos fardados, não tardaram em aparecer.

A END avança em relação aos dois documentos de Política Nacional de Defesa que a precederam. Contempla aspectos que naqueles haviam sido insuficientemente tratados e se atreve a desenhar a definição do que poderíamos chamar "Grande Estratégia" no sentido que dá à expressão Liddel Hart. ${ }^{26}$ Em realidade, e ainda que se centre na defesa, a END se estende a aspectos como a educação, ciência e tecnologia, economia, infra-estrutura e mobilização nacional, entre outros. Avança sobre a organização das FA, sua composição organizacional e suas práticas operacionais, assim como sobre as capacidades e os meios necessários para assegurar sua eficácia. Pensou-se na independência tecnológica para suprir esses meios, e na articulação com a indústria nacional reforçada com proteção e auxílio econômico para a produção de materiais de defesa de maneira autônoma. Menciona o desenvolvimento científico-tecnológico nas áreas cibernética, aeroespacial e, especialmente, nuclear.

O documento estrutura a Defesa Nacional em três eixos principais: a organização das FA, orientando-as para um melhor desempenho no cumprimento de seu papel constitucional; a reorganização da indústria nacional de material de defesa para equipar as forças com autonomia e tecnologia nacional e a composição dos efetivos das FA e a mobilização nacional pelo alongamento e aprofundamento do Serviço Militar Obrigatório (SMO) e a implementação de um Serviço Civil Obrigatório subscrito ao Ministério de Defesa.

Uma primeira consideração de peso do documento associa indissoluvelmente a estratégia de desenvolvimento do país àquela da defesa. Talvez inspirados pelo binômio conceitual "Segurança e 
Desenvolvimento" que com certa frequência apareceu nos últimos documentos da Organização dos Estados Americanos, ou apoiados na falácia do "spin of" da Pesquisa e Desenvolvimento (P\&D) em ciência e tecnologia da defesa para a indústria civil, ${ }^{27}$ neste documento foi substituído o conceito de "Segurança" pelo de "Defesa" para afirmar a inseparabilidade da Estratégia de Defesa Nacional da Estratégia de Desenvolvimento Nacional e que "Cada uma reforça as razões da outra. Em ambas, se desperta para a nacionalidade e se constrói a nação" (END, p.2) ${ }^{28}$. A costura entre ambas se configuraria, segundo o documento, pelo fortalecimento de três setores considerados estratégicos: o espacial, o cibernético e o nuclear. Sem especificar qual ministério conduziria o desenvolvimento científico nestas áreas, garante que "por sua própria natureza, esses setores transcendem a divisão entre desenvolvimento e defesa, entre o civil e o militar" (END, p.5). Finalmente, e apesar do Brasil se autoproclamar como um país pacífico e ter ratificado o Tratado de Não Proliferação Nuclear (TNP), o documento reafirma "a necessidade estratégica de desenvolver e dominar a tecnologia nuclear" e mais adiante, quando trata especificamente da Marinha, confessa a decisão nacional de adquirir meios navais de propulsão nuclear, especialmente o velho sonho da Marina: a fabricação do submarino nuclear (END, p.16).

Em 26 de agosto de 2008, o Almirante Júlio Soares de Moura Neto, Comandante da Marinha, declarou que o prazo máximo para entregar o submarino nuclear brasileiro seria 2021. A primeira fase do processo, que envolve o enriquecimento de urânio, já está concluída e tudo indica que o casco será construído com a cooperação da França. A construção do submarino nuclear, previsto na END, poderá custar 600 milhões de dólares, mais do dobro do necessário para construir um submarino convencional. Ainda assim, e segundo a avaliação do almirante na reserva Othon Luiz Pinheiro da Silva, precursor do projeto do submarino nuclear brasileiro em 1979, a Marinha brasileira precisaria de seis submarinos nucleares para proteger a plataforma continental do Brasil pelo seu tamanho ${ }^{29}$.

O objetivo principal declarado pela END sobre mobilidade e presença é contar com uma força militar suficiente para dissuadir "a concentração de forças hostis" nas fronteiras nacionais (END, p.4). Para satisfazer este objetivo, propõe o desenvolvimento de três capacidades: seguimento e controle, mobilidade e presença. Devido à dimensão territorial do Brasil, a ênfase é colocada na mobilidade estratégica para chegar ao teatro de operações rapidamente e na mobilidade tática para dominar esse teatro pelo deslocamento em seu interior. Essa mobilidade tática e estratégica permitiria cobrir toda a extensão territorial nacional e responder rápida e contundentemente frente a qualquer agressão ou ameaça em todo o território nacional. Contudo, esta prioridade vê-se comprometida com o tratamento dado na END à "presença" - que insiste em distinguir da "onipresença" - uma vez que "o esforço de presença, sobretudo ao longo das fronteiras terrestres e nas partes mais estratégicas do litoral, tem limitações intrínsecas" (END, p.4), talvez influenciada 
pelo lugar da Amazônia na mística militar propõe "adensar a presença de unidades do Exército, da Marinha da Força Aérea nas fronteiras" (END, p.6).

Ainda que notória, a falta do Estado em vastas regiões das fronteiras nacionais, especialmente nas amazônicas, não vemos a pertinência estratégica de acantonar forças nessas regiões. Ainda reconhecendo a importância de uma maior presença do Estado por meio dos ministérios da Saúde, da Educação, da Justiça e outros, a construção de bases, aeroportos e arsenais ofereceria a logística para uma eventual invasão de uma potência maior (que seria a hipótese para estas preocupações). Sem essa presença militar física, a própria Amazônia é o principal obstáculo para tal invasão e a força poderia estar preservada, preparada, em alerta e com condições de rápido deslocamento para fixar, hostilizar e posteriormente repelir as forças invasoras.

Um terceiro ponto politicamente destacável e coerente com o principio da mobilidade é a proposta de unificar as operações das três forças através da criação do Estado Maior Conjunto (EMC) das FA. Esta tardia inovação representa um importante passo na organização militar, que fortalece o MD e, consequentemente, a condução política da defesa. Do ponto de vista da reorganização militar, cabe ao ministro da Defesa indicar - e ao Presidente nomear - os comandantes de cada força que integrarão o EMC. Estes dirigirão cada uma das Forças, formularão sua política e doutrina e prepararão seus órgãos operativos. Os Estados Maiores de cada força formularão a estratégia respectiva de sua força.

A END projeta a estrutura conjunta ${ }^{30}$ das FA brasileiras também para todas as áreas e regiões de atuação: "Em cada área deverá ser estruturado um EMC, que será ativado para realizar e atualizar, desde o tempo de paz, as planificações operacionais da área" (END, p.6). Para tornar possíveis as reuniões regionais regulares dos comandantes generais de cada Serviço, a END propõe a reagrupação das mesmas para que os distritos Navais ou os Comandos de Área tenham suas áreas de jurisdição coincidentes.

Embora não se tenha discutido a criação de uma Escola de Comando unificada para as três forças - o que tornaria realmente eficaz a "conjunção" das forças -, este aspecto da END recebeu fortes críticas de setores militares, fundamentalmente do Exército. Estes setores, resistentes à mudança, argumentam que a criação do EMC provocaria a perda de identidade de cada força e debilitaria a autonomia dos Estados Maiores atualmente existentes no Exército, na Aeronáutica e na Marinha em relação ao MD. ${ }^{31}$ Esta resistência ficou registrada em discursos de despedida de militares no ato de sua passagem à reserva, impensáveis em democracias consolidadas. Parte destes discursos criticava justamente o que deveria ser um objetivo claro e explicito da política de defesa na democracia: a óbvia consolidação do MD como instrumento de execução da política do governo eleito, único e legítimo detentor do monopólio da força do Estado. ${ }^{32}$ Para alguns militares, o fortalecimento do ministério em relação aos comandos individuais das forças, somado à sua 
prerrogativa para designar os comandantes de cada força, é inaceitável porque essas medidas "trouxeram novamente antigos costumes de politização dos negócios internos das FA". ${ }^{33}$

Um conceito típico da época da ditadura militar, particularmente enfatizado por Geisel, que há muito tempo não se via na literatura brasileira e que reapareceu na END é o de "projeção de poder". O conceito de "potência" é polissêmico e no ambiente das Relações Internacionais pode se referir a diferentes capacidades do Estado, como a militar, a econômica, a cultural, a política, a diplomática e outras $^{34}$. O comportamento internacional do Brasil tem sido ultimamente reconhecido por sua eficiência diplomática e seus bons ofícios no ambiente internacional, particularmente o regional, mais enfaticamente neste cenário desde o final de 2007, com o decidido apoio da "diplomacia presidencial" levada a cabo por Lula. Portanto, "projeção de poder" pode ser lido como "soft power" através do qual o Brasil se destaca nos vários cenários internacionais pelos que transita. Não obstante, na END, a referência a "projeção de poder" aparece fundamentalmente no parágrafo relativo à Marinha, onde trata do aumento do poderio naval e da aquisição de meios de superfície e submarinos nucleares brasileiros. Aqui este conceito fica inequivocamente associado à força: "a projeção de poder se subordina, hierarquicamente, à negação do uso do mar" (END, p.12), a "negação do uso" na passagem citada se refere ao mar continental brasileiro, no qual se encontram alguns dos interesses estratégicos, como as plataformas petrolíferas de águas profundas, ilhas e arquipélagos, portos e vias de comunicação marítima. Não obstante, mais adiante, ao tratar das hipóteses de emprego da força, quando especifica as capacidades desejadas para as FA, aponta expressamente a capacidade de "projeção de poder nas áreas de interesse estratégico" (END, p.42).

Outro conceito interessante, menos pela novidade que por seu reconhecimento explícito, é a reivindicação para o Exército convencional de "alguns atributos" das forças "não convencionais". Não é de se estranhar: frente a facilidade com que as forças norte-americanas penetraram no Iraque, resultou claro, como advertiu o General Erick de La Maisonneuve, que nenhum exército convencional poderia opor-se à vontade de um exército daquele porte. Na circunstância de ofender os interesses de uma superpotência, para este autor, só restam duas alternativas, o salto democratizante até o nível nuclear de beligerância (para quem possua a tecnologia ou possa adquirila) ou descer ao inferno da guerra sub-clássica: guerra de guerrilha e terrorismo. ${ }^{35}$

Notamos que, em países de porte médio e em alguns exércitos sul-americanos, se manifesta a tendência de se preparar para a doutrina que chamamos em outro lugar "estratégia da resistência dissuasória" ${ }^{36}$, isto é, paralelamente à dissuasão convencional, estes exércitos se preparam de forma explícita para enfrentar uma prolongada resistência não convencional:

Um exército que conquistou os atributos de flexibilidade e de elasticidade é um exército que sabe conjugar as ações convencionais com as não convencionais. A guerra assimétrica, no quadro de uma guerra de resistência nacional, representa uma efetiva possibilidade da doutrina aqui especificada (END, p.18). 
Na explicitação deste preparo reside sua eficácia dissuasória: a estratégia consiste em não empregar o esforço maior para evitar a invasão, mas sim em mostrar-se preparado e politicamente decidido para resistir à permanência do exército invasor, desestabilizar o governo ocupado e evitar a administração estrangeira.

O reparo que é possível fazer a este propósito é sobre a especialização desse combatente apenas para o ambiente de selva. Se bem que concordamos que "os imperativos de flexibilidade e de elasticidade culminam no preparo para uma guerra assimétrica" (END, p.18) nos parece que apenas preparar "um combatente detentor de qualificação e de rusticidade necessárias à proficiência de um combatente de selva" (END, p.18) é restringir o ambiente da resistência. Essa doutrina deixa de lado o ambiente urbano, no qual teoricamente se alocaria a administração invasora e onde os golpes da resistência teriam maior impacto midiático e permitiria a articulação com forças políticas em resistência para organizar a insurgência. Fora da hipótese de um recorte do território amazônico por forças estrangeiras superiores em potência, a ideia de que uma potência superior invada o Brasil pelo território da selva amazônica, suportando as penúrias que representa esse cenário, podendo atacar diretamente os centros de gravidade nacional com uma força aérea praticamente invisível e inalcançável para a artilharia antiaérea convencional, parece pouco plausível.

Para adequar seu desempenho às missões constitucionais, tanto em tempos de paz quanto de guerra, o Exército deverá seguir os preceitos estratégicos da flexibilidade e da elasticidade. Por flexibilidade, a Estratégia entende a falta de rigidez no emprego da força e, recuperando a Lidell Hart, afirma que consiste na "capacidade de deixar o inimigo em desequilíbrio permanente, surpreendendo-o por meio da dialética da desconcentração e da concentração de forças" (END, p.15).

A insistência no SMO e seus alargamentos parece encaixar-se na ideia da "estratégia da resistência dissuasória" e da "elasticidade" que se espera conferir à força. Com este conceito a END se refere à capacidade de aumentar a dimensão das forças em casos de necessidade de uma mobilização em grande escala de recursos humanos e materiais para defender o país. A disponibilidade desta capacidade exige a existência de reservas provenientes do SMO, o qual também teria a função de integrar as FA à Nação o que permitiria dispor da logística popular necessária para uma resistência prolongada. ${ }^{37}$

Não obstante, a renovação da ideia do SMO, na contramão da formação dos exércitos mais atualizados, parece contrastar com a proposta de Forças de Ação Rápida Estratégica que exige em sua composição recursos humanos altamente capacitados, treinados e armados para operar nos mais diversos terrenos e condições, além de operar meios de comunicação e de armamentos de altíssima tecnologia "desde os menos sofisticados, tais como radar portátil e instrumental de visão noturna, até as formas mais avançadas de comunicação entre as operações terrestres e o monitoramento 
espacial" (END, p.16). A instrução e o treinamento específico para este tipo de soldados distam muito do que se pode oferecer a um conscrito, em tempo, profundidade e especificidade. No entanto, o soldado recruta requer a atenção dos oficiais e sargentos durante pelo menos seis meses de treinamento para realizar funções meramente subsidiárias em qualquer cenário futuro de guerra.

Ademais, o peso orçamentário do SMO consumiria recursos que poderiam promover a profissionalização, a pesquisa em ciência e tecnologia para a defesa ou o investimento em meios. Sua implementação reduziria o tempo, recursos e atenção das FA necessários para sua preparação operativa ao se dedicar à formação de conscritos. Finalmente, a integração entre a nação e suas FA pode ser alcançada por outros meios mais eficientes, do que pelo alistamento obrigatório, como os políticos e culturais, que democratizem os temas da defesa e permitam aos cidadãos tomar consciência de seus deveres para com ela, ${ }^{38}$ uma mentalização que não se confunde necessariamente com o prosaico "pegar em armas". Depois de tudo, "o engajamento de toda a Nação em sua própria defesa" (END, p.15) não pode significar simplesmente "a nação em armas" ainda que em determinados momentos possa exigi-lo.

\section{Lei complementar $N^{\circ} 136$ e Decreto 7274/10, de 25 de agosto de 2010}

A última realização no caminho da consolidação do poder civil sobre o militar, como preparatório para conceder àqueles a condução política da Defesa, foram a promulgação da Lei 136 e o decreto 7274. Embora tenha passado inadvertido para muitos, estes documentos são de grande importância na estruturação da cadeia de comando das FA e o fortalecimento da democracia. Por um lado, a Lei 136 altera a Lei Complementar $n^{\circ}$ 97, de 9 de junho de 1999, que "dispõe sobre as normas gerais para a organização, o preparo e o emprego das Forças Armadas", cria o Estado-Maior Conjunto das Foras Armadas e regula as atribuições do Ministério da Defesa. No seu Artigo $3^{\circ}$-A afirma que,

O Estado-Maior Conjunto das Forças Armadas, órgão de assessoramento permanente do Ministro de Estado da Defesa, tem como chefe um oficial-general do último posto, da ativa ou da reserva, indicado pelo Ministro de Estado da Defesa e nomeado pelo Presidente da República, e disporá de um comitê, integrado pelos chefes de Estados-Maiores das 3 (três) Forças, sob a coordenação do Chefe do Estado-Maior Conjunto das Forças Armadas.

O Estado-Maior Conjunto, com essas características, cria mais um degrau na cadeia de comandos, o que diminui a força dos comandantes de cada uma das forças e, concomitantemente, aumenta o poder do Ministério da Defesa. Sobre a autoridade dos comandantes de cada uma das forças, se estipula a coordenação de um chefe do Estado-Maior Conjunto, indicado diretamente pelo ministro, o que reforça esse degrau. Esse chefe, se estiver na ativa, é passado para a reserva (§1) mas com o mesmo grau de precedência hierárquica que os comandantes das outras três forças $(\S 2)$ e 
conservando todas as prerrogativas, direitos e obrigações dos oficiais-gerais da ativa (§3). Outra atribuição deste chefe do Estado-Maior Conjunto é participar como membro nato do Conselho Militar de Defesa (Art. $2^{\circ} \ldots .1^{\circ}$ ).

Finalmente, ao ministro reserva, além da elaboração do orçamento do Ministério da Defesa e junto às Forças Armadas, do orçamento correspondente às forças,

formular a política e as diretrizes referentes aos produtos de defesa empregados nas atividades operacionais, inclusive armamentos, munições, meios de transporte e de comunicações, fardamentos e materiais de uso individual e coletivo, admitido delegações às Forças (Art. 11-A).

Se por um lado com esta lei o governo Lula disponibiliza um instrumento institucional para um melhor controle e comando político da Defesa, por outro, o Decreto 7274, do mesmo dia que a Lei, aponta ao preparo dos funcionários públicos, civis e militares, que tornaram eficiente aquela estrutura institucional, desde que, como disse no seu Artigo $1^{\circ}$, "Este Decreto dispõe sobre a Política de Ensino de Defesa - PensD”. A proposta embutida neste decreto objetiva incrementar o estudo de temas relativos à Defesa Nacional estimulando à sociedade para se aprofundar nesta nova área epistêmica, "em particular no meio acadêmico, capacitando recursos humanos, conforme as necessidades dessa área" (Art. $3^{\circ}$ ). Pela sua importância para os Estudos Estratégicos, de Historia Militar e da Guerra e os Estudos que abordam o tema de Relações Civil-Militares, anotamos por extenso os objetivos específicos deste decreto:

I - cooperação na área do ensino de defesa com outros países, em consonância com a política externa brasileira, em especial na América do Sul;

II - difusão dos assuntos de interesse da defesa nacional no meio acadêmico civil;

III - promoção de estudos e estímulo ao desenvolvimento da capacidade de liderança, em cursos da área de defesa nacional;

IV - capacitação de recursos humanos da área de inteligência, com ênfase na elaboração de documentos prospectivos e na análise nos campos científico, nuclear, cibernético e espacial;

$\mathrm{V}$ - equivalência de cursos nos sistemas de ensino civil e militar, no que for aplicável, respeitadas as respectivas legislações de ensino;

VI - promoção, de forma sistemática e permanente, da capacitação do pessoal civil e militar da área de defesa;

VII - intercâmbio entre instituições de ensino civis e militares;

VIII - participação de representantes dos órgãos da administração pública federal nos cursos da Escola Superior de Guerra;

IX - desenvolvimento da mentalidade e da doutrina de operações conjuntas, por intermédio do ensino;

$X$ - difusão de conhecimentos relativos às operações de paz, em instituições de ensino;

XI - difusão de conhecimentos relativos à mobilização nacional, em instituições de ensino;

XII - interação entre cursos congêneres das Forças Armadas e da Escola Superior de Guerra, com ênfase nos cursos de altos estudos; e

XIII - aprimoramento do perfil dos militares das Forças Armadas, por meio da valorização dos princípios da iniciativa e da flexibilidade, nos cursos militares de carreira. ${ }^{39}$ 
Com este decreto fecha-se o círculo que, dependendo da vontade e do cálculo político, poderá redundar numa consolidação do controle civil dos militares e na efetiva condução política da Defesa, como se espera de um regime democrático sem adjetivações. O governo Lula está chegando ao seu fim e o êxito do mesmo refletiu-se na escolha da sua sucessora, a ex-ministra Dilma Rousseff. A esta altura seria um exercício de futurologia imaginar o destino das instituições brasileiras. De algumas entrevistas com oficiais-gerais ficamos com a impressão de que, embora não se possa falar de uma posição monolítica dentro dos quadros das Forças Armadas, há a sensação de certa predisposição por parte dos militares de aceitar a subordinação não apenas formal, mas também material, isto é, obedecer na relação de mando e obediência ao poder legitimamente constituído o que, no caso da democracia, é aquele que emerge da vontade popular expressada nas urnas.

\section{Considerações finais}

Em quase todas as crises de subordinação militar nas relações entre civis e militares, em que abriram-se oportunidades para que o poder político tivesse a possibilidade de se impor às FA para diminuir sua autonomia ou restringir suas prerrogativas, foram estas últimas que saíram fortalecidas do embate. Não obstante, neste período foi promulgado o segundo documento de PND, finalmente apresentada a END que vem de fato a fortalecer o MD. Todavia, esse fortalecimento dependerá da atitude civil na condução política da Defesa, por tanto, da formação de acadêmicos que pensem a Defesa em todas as suas dimensões e de funcionários públicos eficientes para a transmissão da vontade política sobre as questões da Defesa. A Lei 136 tem o claro propósito de fornecer as condições institucionais para solidificar esse fortalecimento. O conteúdo de este dispositivo institucional está dado pelo decreto 7274/10, que se propõe formar os quadros civis capacitados para se inserir naquela estrutura desenhada pela 136 e funcionar como cadeia de transmissão da vontade democrática encarnada pelo Executivo nacional. A dificuldade de que todo esse andaime institucional e o projeto formativo funcionem é que a sociedade brasileira pouco se importa com as questões da Defesa e na academia ainda reina o preconceito e a discriminação contra as reflexões a respeito. Ante esta alternativa, as FA permanecem ocupando os espaços vazios deixados pelos civis nos âmbitos de deliberação e continuam recuperando fontes de decisão que os políticos sequer reclamam. Esta situação fragiliza a democracia atrofiando o exercício normal de controle civil sobre os militares e de condução política da Defesa. Fragilidade que nestes âmbitos indica claramente a fragilidade democrática. 


\section{Referências Bibliográficas}

CANTANHÊDE, Eliana. A guerra não acabou. Folha de S. Paulo On Line, 27 de Junho de 2007, Pensata. www. folha.com.br/Brasil

COELHO, Edmundo Campos. Em busca de identidade. Rio de Janeiro: Record, 1987.

Decreto Lei 200 de 1967. http://www.planalto.gov.br/Ccivil_03/Decreto-Lei/Del0200.htm.

Decreto $\mathrm{n}^{\circ} 7.274$, de 25 de agosto de 2010

FERREIRA, Oliveiros. Vida e Morte do Partido Fardado. São Paulo: Senac, 2000.

FLEMMES, Daniel. Instituition Building in Mercosul's Defence and Security sector. Brazil's

Defence Cooperation between dominant armed services and marked biateralism. Hamburg, Germany. Institute for Iberoamerican studies, 2004. Work Paper IIK, n. 20.

FUCILLE, Luis Alexandre. A criação do Ministério da Defesa no Brasil: inovação e continuidade. Research and Education in Defense and Security Studies, August, 2002.

HART, L. Strategy. NY: Praeger Paperbacks, 1954.

LA MAISONNEUVE, E. La Violence qui vent. París: Les Éditions Arléa, 1997.

Lei complementar $\mathrm{N}^{\circ} 136$ e Decreto 7274/10, de 25 de agosto de 2010

MARTINS FILHO, João Roberto. As FA brasileiras e o Plano Colômbia. In: CASTRO, Celso (org). Amazônia e Defesa Nacional. Rio de Janeiro: FGV, 2006.

MATHIAS, Suzeley Kalil. Distensão no Brasil. O projeto militar 1973-1979. Campinas: Papirus, 1994.

MYIAMOTO, Shiguenoli. Geopolítica e Poder no Brasil. Campinas: Papirus, 1995.

OLIVEIRA, Eliézer Rizzo de. De Geisel a Collor. FA, Transição e Democracia. Campinas: Papirus, 1994.

REBELO, Aldo; FERNANDES, Luis (org.) Política de Defesa para o Século XXI, Brasília, Câmara dos Deputados - CREDN, 2003.

SAINT-PIERE, Héctor L.; WINAND, Érica C. A. Dangerous Ambiguity. Proposes to expand the role of the Brazilian armed forces. Hemisphere, volume 16, Spring, 2006.

SAINT-PIERRE H.L. ; BIGATÃO J.P. "Las mutantes máscaras de Marte” em TAMAYO, A.M.: Conocer la guerra, construir la seguridad. Lima, Instituto de Defensa Legal, 2008.

SANTOS, Maria Helena de Castro. A nova missão das FA latino-americanas no mundo Pós-Guerra Fria: o caso do Brasil. Revista Brasileira de Ciências Sociais, vol.19, no. 54, fevereiro de 2004.

SOUZA, Maria do Carmo Campelo. A Nova República brasileira: sob a espada de Dâmocles. In: STEPAN, Alfred (org.). Democratizando o Brasil. Rio de Janeiro: Paz e Terra, 1988. 
STEPAN, Alfred (org.). As prerrogativas militares nos regimes pós-autoritários: Brasil, Argentina, Uruguai e Espanha. In: STEPAN, Alfred. Democratizando o Brasil. Rio de Janeiro: Paz e Terra, 1988.

TSE-TUNG, Mao, Selección de Escritos Militares. Pekín: Ediciones en Lenguas Extranjeras, 1967.

ZAVERUCHA, Jorge. FHC, FA e Polícia. Entre o autoritarismo e a democracia. Rio de Janeiro: Record, 2005.

\section{Sites e arquivos eletrônicos}

Decreto Lei 200 de 1967. http://www.planalto.gov.br/Ccivil_03/Decreto-Lei/Del0200.htm. http://www1.folha.uol.com.br/folha/brasil/ult96u65505.shtml Isto É On line: http://www.terra.com.br/istoe/1620/brasil/1620mobilizacao.htm www.defesa.gov.br www.defesanet.com.br www.exercito.gov.br/notícias www.iugm.es/ADEFAL. www.mre.gov.br WwW.oas.org www.observatorioconosur.com.ar

\section{NOTAS}

${ }^{1}$ www.defesa.gov.br

${ }^{2}$ No entanto, lendo o referido decreto, não constatamos a clareza de tais objetivos. O documento parece frisar a importância dos Ministérios de Estado de cada força e não o contrário. Confrontar: http://www.planalto.gov.br/Ccivil_03/Decreto-Lei/De10200.htm

${ }^{3}$ Como, por exemplo, Zaverucha, 2005, p.215.

${ }^{4}$ www.defesa.gov.br

5 Apesar de denotar o revigoramento do interesse civil pelo tema, a verdade é que a Defesa não está totalmente desmilitarizada, do ponto de vista de quem a articula.

${ }^{6}$ Ver: Organograma do Ministério da Defesa: www.defesa.gov.br

${ }^{7}$ De acordo com Fucille (2002, p.4), "Dadas as peculiaridades e singularidades da profissão militar, ao lado do forte sprit de corps que a instituição possui, muitas vezes o controle/supremacia civil tem sido dificultado em nome de um conhecimento tecnocrático exclusivo que leva os militares a reclamarem autonomia frente a todo controle externo. Aqui entra um problema fundamental. Mais do que apenas verificar se um dado país possui ou não um Ministério da Defesa, há que se estar atendo aos moldes deste, ou seja, que áreas são por ele efetivamente controladas e com civis à frente". 8 De acordo com a Folha de S. Paulo, "a divulgação de fotos que supostamente mostrariam o jornalista Vladimir Herzog momentos antes de sua morte, nos estabelecimentos do DOI-Codi, provocou a crise entre o Palácio do Planalto e o Ministério da Defesa que levou ao pedido de demissão do ministro José Viegas." Antes de dadas como falsas as fotos, o Exército divulgou uma nota elogiando práticas adotadas durante o regime militar contra militantes de esquerda. Segundo o jornal, "Lula ficou descontente com o teor da nota e criou-se a impressão de que Viegas não tinha autoridade sobre o Exército". Porém, ao invés do Comandante ser repreendido, foi o Ministro da Defesa quem "renunciou" ao cargo, alegando sua responsabilidade pelo mau comportamento do Exército, por ser ele, o dirigente superior das Forças Armadas. Folha de S. Paulo - Brasil - 04/11/2004. Ver: http://www1.folha.uol.com.br/folha/brasil/ult96u65505.shtml Caso semelhante ocorreu em outubro de 2000: o presidente Fernando Henrique Cardoso tentou demitir o Comandante do Exército, General Gleuber Vieira, mas foi pressionado pelas Forças Armadas a recuar de sua decisão, conforme relatou a revista Isto $E_{\text {: }}$ "Insatisfeito com as pressões da caserna por mais verbas e um imediato aumento salarial, [...] Fernando Henrique resolveu demitir o comandante do Exército, general Gleuber Vieira. FHC não gostou de uma entrevista dada pelo general criticando a falta de verbas. Ele anunciou sua decisão em uma conversa com o ministrochefe do Gabinete de Segurança Institucional, general Alberto Cardoso, e com o ministro da Defesa, Geraldo Quintão. A determinação repercutiu muito mal nos quartéis e foi considerada inaceitável por generais e coronéis. Antecedida de visitas do comandante do Exército a quartéis País afora, uma reunião em Brasília com todos os 155 generais, e sem 
convite a Quintão, foi o palco escolhido pelos militares para um desagravo a Gleuber Vieira e uma explícita manifestação de descontentamento com o governo e seu tratamento dispensado à Força. A pressão funcionou. Alertado pelo serviço de informação do Palácio do Planalto, Fernando Henrique desistiu da demissão e escalou o general Cardoso para atuar como bombeiro junto ao generalato. Ele informou aos colegas de farda que Gleuber não mais seria demitido e acertou que os militares não fariam nenhuma manifestação pública". Ver: Isto É On line: http://www.terra.com.br/istoe/1620/brasil/1620mobilizacao.htm

${ }^{9}$ Os parlamentares que tratam do assunto relativo à Defesa Nacional participam da Comissão de Relações Exteriores e Defesa Nacional (CREDN), mas seus cargos são rotativos, sendo que a cada 2 anos são trocados. Esta rotatividade impede a formação de uma cultura da defesa, de uma especialização dos parlamentares com os assuntos ai tratados que, por sua vez, são divididos com o interesse (escasso também) pelas relações externas. Esta falta de profissionalização parlamentaria e de desconhecimento do assunto deixa nas mãos da assessoria da CREDEN ou a dos parlamentares muitas das decisões, sendo que muitos desses assessores são militares. Por outro lado, o desaso, despreparo e desinteresse parlamentar pelo tema, facilita o trabalho do lobby militar nas resoluções do interesse da corporação, como as relativas ao orçamento das FA.

${ }^{10}$ É preciso salientar que apenas a criação do Ministério da Defesa não é o bastante para garantir que os militares não se salientem na cena política, como mostra Fucille (2002, pp.4-5): “o Brasil foi o último país sul-americano a criar seu Ministério da Defesa. Não obstante, recentemente a região foi sacudida não por golpes militares, mas por graves crises político-institucionais onde as Forças Armadas desempenharem um destacado papel de "arbitragem", conforme foi possível perceber no Equador, Peru, Venezuela e Paraguai. [...] O Chile, por exemplo, nosso parceiro especial do Mercosul e de regime militar - guardadas as devidas diferenças - possui um Ministério da Defesa há décadas, inclusive ocupado por um civil, e nem por isso o nível de autonomia gozado pelos militares chilenos é baixo. Baseado em Janowitz (1974), o autor acredita que o sucesso deste processo de subordinação dos militares ao poder civil depende da criação de "canais adequados para a expressão dos interesses profissionais militares, bem como infundir nas Forças Armadas a confiança de que seus interesses institucionais essenciais estão sendo razoavelmente atendidos. Para ele, os militares devem ser "punidos" e "recompensados" de acordo com sua atitude, principalmente no caso brasileiro, no qual constatamos um histórico de acentuado protagonismo militar e de fragilidades institucionais.

${ }^{11}$ Exemplo disto foi seu êxito em demitir o Ministro do Exército Sylvio Frota.

$12 \mathrm{Na}$ prática, esta "tutela" militar se traduziu em "pressões de diversas ordens sobre o Congresso Constituinte, envolvendo interesses sobre as definições da função constitucional, o regime presidencialista e o mandato presidencial". Oliveira, 1994, p.122.

${ }^{13}$ As Forças Armadas são formadas pela Marinha, Exército e Aeronáutica, instituições nacionais permanentes e regulares, organizadas com base na hierarquia e na disciplina, sob a autoridade suprema do Presidente da República. A regulação das competências fundamentais sobre definição dos objetivos da Defesa é feita pela Política de Defesa Nacional, aprovada em 30 de Junho de 2005 pelo decreto $n^{\circ}$ 5.484, sob coordenação do Ministério da Defesa. Tem a função precípua de defender a Pátria, garantir os poderes constitucionais e, por iniciativas de qualquer destes da lei e da ordem. Tem como atribuições subsidiárias, em conjunto, cooperarem com o desenvolvimento nacional e a defesa civil. Como atribuições particulares: À Marinha: orientar e controlar a Marinha Mercante e suas atividades correlatas, no que interessa à defesa nacional; prover a segurança da navegação aquaviária; contribuir para a formulação e condução de políticas nacionais marítimas; e implementar e fiscalizar o cumprimento de leis e regulamentos, no mar e águas interiores; À Aeronáutica: orientar, coordenar e controlar as atividades de Aviação Civil; prover a segurança da navegação aérea; contribuir para a formulação e condução da Política Aeroespacial Nacional; estabelecer, equipar e operar, diretamente, ou mediante concessão, a infra-estrutura aeroespacial e operar o Correio Aéreo Nacional.

${ }^{14}$ Sobre esta questão ver: SAINT-PIERRE; WINAND, 2005.

15 As informações encontram-se no jornal $O$ Estado de S. Paulo, São Paulo, 10 de setembro de 2.002, p. A4. In: Observatório Cone Sul de Defesa e FA. www.observatorioconosur.com.ar.

16 Estas reuniões tiveram início no dia 13 de setembro de 2.002, no intuito de ouvir de todos os candidatos quais eram suas propostas de solução do problema das FA. Os encontros foram promovidos pelo então presidente do Centro de Estudos Estratégicos da Escola Superior de Guerra (ESG), Leônidas Pires Gonçalves, que foi ministro do Exército durante o governo Sarney.

17 Ver link "Notícias" no site Defesanet. Disponível em: $<$ http// www.defesanet.com.br

18 Ver: Discurso do Sr. Ministro do Estado da Defesa, José Viegas Filho, no clube militar do Rio de Janeiro, em 25 de fevereiro 2.003 no site Defesanet. Disponível em:<http// www.defesanet.com.br..

19 Pode-se consultar o discurso completo no site do Exército brasileiro. Disponível em: <http// Www.exercito.gov.br/noticias.

${ }^{20}$ Agrega ao seu discurso: "Em 2003, o Brasil continuará a se fazer presente no Timor Leste, o que acontece desde 1998, participando do esforço de consolidação da paz nesse país amigo. O papel da Força Aérea será o de apoiar o transporte dos pelotões brasileiros, a cada seis meses, quando são percorridos, em cada viagem, cerca de 34 mil quilômetros. Na Europa, o Brasil far-se-á representar na Missão de Observadores das Nações Unidas em Prevlaka, Croácia (Unmop), com observadores militares, e na Força das Nações Unidas em Chipre (Unficyp), participando do Estado-Maior do contingente argentino. Nas Américas, o Brasil continuará participando da Missão de Verificação dos Direitos Humanos das Nações Unidas na Guatemala (Minugua) e da Missão de Assistência à Remoção de Minas na América Central (Marminca), com supervisores internacionais da Marinha e do Exército. A missão Marminca, cujos 
recursos provêm da OEA, é gerenciada pela Junta Interamericana de Defesa - JID, com atuação na Costa Rica, Nicarágua, Guatemala e Honduras".

${ }^{21}$ Pronunciamento do Ministro de Estado da Defesa, José Viegas Filho no Instituto Rio Branco, no dia 18 de Março de 2004. Ver: www.mre.gov.br.

${ }^{22}$ Documento de Política de Defesa Nacional, 2005. Disponível em: https://www.defesa.gov.br/pdn

${ }^{23}$ JOBIN, N.: "Defesa, democracia e desenvolvimento" em Tendências e Debates (Jornal Folha de SPaulo, 13.04.2009)

${ }^{24}$ JOBIM, N.: "La defensa de la prosperidad sudamericana" in DEF. Buenos Aires: ed. TAEDA Año 4, No 43. Marzo 2009, p.77.

${ }^{25}$ Não posso considerar a convocação pinçada de um e outro acadêmico para "conversar" com o ministro Mangabeira Hunger como a realização do "grande debate" nem sequer como debate, nem no sentido estrito da palavra nem no sentido político da proposta.

${ }^{26}$ HART, L. Strategy. NY: Praeger Paperbacks, 1954.

27 Não há prova empírica de que o esforço nacional em P\&D em ciência e tecnologia para a defesa promova desenvolvimento econômico-social, nem sequer que induza avanços justificados para a ciência e tecnologia civil. Não existem casos históricos -salvo nas grandes superpotências- nos quais se tenha constatado claramente um aumento considerável do emprego nem do PIB nacional por essa custosa inversão social. Não é preciso justificar o esforço em tecnologia autônoma em qualquer área estratégica por parte de um país que decida emergir entre as potências mundiais, mas não se pode ocultar o custo que esse esforço significa para o país e a inevitável postergação de outras prioridades nacionais, como diminuir as vulnerabilidades com investimentos em saúde pública, serviços sanitários básicos, na educação fundamental ou mesmo, inclusive, diretamente na ciência e tecnologia civil ou/e no financiamento do desenvolvimento de processos produtivos civis.

28 Pode-se consultar a versão traduzida para o castelhano do documento em: https://www.defesa.gov.br/eventos_temporarios/2008/estrat_nac_defesa/estrategia_defesa_nacional_espanhol.pdf. (visitado en 14/05/2009).

29 "Informe Brasil” em Observatório Cone Sul de Defesa e FA. 27-29/09/2008

${ }^{30}$ É digna de menção uma curiosidade: no Brasil as operações militares entre as diferentes forças sempre foi chamado "combinadas" e as operações com forças de outros países eram referidas como "conjuntas". Neste documento se inverte a nomenclatura adequando-a à semântica do resto da sub-região, que se refere por "conjunto" ao esforço das três forças e combinado quando compartilhado com outro(s) país(es).

${ }^{31}$ Ver "Exército critica plano de defesa e vê comandos enfraquecidos" Folha de São Paulo, 04 de março de 2009

${ }^{32}$ Pelo contrario, o Governo expressa que "O Ministro da Defesa exercerá, em plenitude, todos os poderes de direção das FA que a Constituição e as leis não reservarem, expressamente, ao Presidente da República. A subordinação das FA ao poder político constitucional é pressuposto do regime republicano e garantia da integridade da Nação (END: p.5).

33 General Luiz Cesário da Silveira Filho "Carta a um Jobim fora do tom" em Jornal do Brasil 17/03/2009, http://jbonline.terra.com.br/pextra/2009/03/17/e170323982.asp, consultado em 15/05/2009.

${ }^{35}$ LA MAISONNEUVE, E. La Violence qui vent. París: Les Éditions Arléa, 1997. Especialmente Cap. 1.

${ }^{36}$ Referimos-nos ao texto SAINT-PIERRE H.L. e BIGATÃO J.P. "Las mutantes máscaras de Marte" em TAMAYO, A.M.: Conocer la guerra, construir la seguridad. Lima, Instituto de Defensa Legal, 2008.

37 Várias considerações da END nesse sentido parecem fortemente inspiradas em reflexiones de Mao Tse-Tung, especialmente as contidas em "Problemas estratégicos de la guerra revolucionaria" e "Sobre la guerra prolongada" in TSE-TUNG, Mao, Selección de Escritos Militares. Pekín: Ediciones en Lenguas Extranjeras, 1967.

${ }^{38}$ Sobre a mobilização nacional, Mao dizia que "Primeiro, consiste em explicar ao exército e ao povo o objetivo político da guerra. Deve-se deixar claro para cada soldado e cada civil por que é necessário combater e o que tem a ver a guerra com eles" tradução minha, em "Sobre la guerra prolongada" Op. Cit., pag. 253.

${ }^{39}$ Decreto $\mathrm{n}^{\circ} 7.274$, de 25 de agosto de 2010, Art. 4o

Artigo recebido em 10/2010. Aprovado em 11/2010. 